\title{
Response of Valencia Orange Trees to Foliar Application of Some Antioxidants (Ascorbic and Salicylic Acids), Magnesium and Micronutrients
}

\author{
Mahamoud R. Gad El- Kareem and Mohamed A. Hussein ${ }^{1}$
}

\begin{abstract}
This study was carried out during 2018/2019 and 2019/ 2020 seasons. On Valencia orange trees are grown in al kawamil orchard at the faculty of agriculture, sohag university, where the soil texture is sandy. The selected trees had the same vigor. This study aimed to throw some light on the effect of single and combined applications of some antioxidants $(300 \mathrm{ppm}$ ascorbic and $300 \mathrm{ppm}$ salicylic acids), 1\% magnesium and a mixture of micronutrients (300 ppm Fe, 200 ppm $\mathrm{Zn}, 200$ ppm Mn) on some vegetative growth characters, fruit set $\%$, fruit retention \%, tree nutritional status, number of fruits per tree, yield and physical and chemical characteristics of fruits. Selecting the best-combined treatment from these antioxidants, magnesium and micronutrients responsible for gaining an economical yield is considered another target.

Single and combined applications of these compounds were very effective in enhancing Main shoot length, shoot thickness, leaf area, fruit set \%, Fruit retention\%, nutrients in the leaves ( $\mathrm{N}, \mathrm{P}, \mathrm{K}, \mathrm{Mg}, \mathrm{Zn}, \mathrm{Fe}$ and $\mathrm{Mn})$, Number of fruits per tree, yield as well as physical and some chemical characteristics of the fruits in relative to the check treatment.

The best results about yield quantitively and qualitatively of Valencia orange trees were obtained when the trees received three sprays (growth start, just after fruits setting and one month later) of a mixture containing 300 ppm salicylic acid, micronutrients and $1 \%$ magnesium sulphate).
\end{abstract}

Key words: Antioxidants, magnesium, micronutrients and Valencia orange.

\section{INTRODUCTION}

Valencia orange tree cultivated in newly reclaimed land such as sandy soil is deficient in nutrient content, low organic matter levels, and lower in capturing water, with high losses of leaching nutrients leading to decreased nutrient content. Consequently, it harms the vegetative growth, yield, and fruit quality of orange trees. New horticultural practices could be accomplished using new safe stimulants for the environment, like antioxidants (ascorbic and salicylic acids) and nutrients, namely magnesium and micronutrients.

Several biochemical effects have been attempted to enhance plant growth and development on different plant species. They are often used as the foliar spray from these compounds' ascorbic acid (Dehghan et al., 2011). Salicylic acid (SA) signal molecules are endogenous plant growth compounds that play a crucial role in plant growth and development and respond to environmental stresses. These signal molecules are involved in specific signal transduction systems, which cause particular enzymes catalyzing biosynthetic reactions to form defense compounds such as polyphenols, alkaloids or pathogenesis-related (PR) proteins (Van Loon, 1995). Other functions assigned to SA are improving chlorophyll and carotenoid pigments, photosynthetic rate, and modifying some essential enzymes' behavior. (Hayat and Ahmad, 2007). Ascorbic acid is an organizer of plant growth and development due to its impact on cell division and differentiation. It includes many essential functions such as antioxidants, photoprotection, photosynthesis, and growth regulation. (El-Sayed et al., 2000) Mentioned that foliar spray with ascorbic acid gave the best yield and fruit quality of Flame seedless grapevine.

Salicylic acid is a plant hormone group (Raskin et al., 1999) and has multiple regulatory functions in plant metabolism (Popova et al., 1997). Salicylic acid is directly involved in plant development, thermogenesis, flower induction, and ion uptake (Raskin, $1992 \mathrm{a}$ and b). Its improvement of chlorophyll and carotenoid pigments, photosynthetic, and modifying some essential enzymes' action are other functions assigned to salicylic acid (Gordon et al., 2002).

Consequently, a tree grown in sandy soil needs more attention in cultural practices like fertilization and foliar spray with some macro and micronutrients. Micronutrients play an essential role in plant nutrition and plant development. Although most micronutrients are affected in the development and function of many enzyme systems, the specific functions of micronutrients in considerable plant variation, micronutrients such as iron, zinc and boron are essential for various biological functions that could be attributed to tree production and fruit quality. (Shoeib, 2003). Increased resistance to diseases and insect pests and improved tolerance to drought (Tariq et al., 2007).

The role of $\mathrm{Zn}$ in the plant influences the synthesis of tryptophan a substrate of Indole acetic acid and the synthesis of the growth substance is greatly affected by

DOI: 10.21608/asejaiqjsae.2021.205326

${ }^{1}$ Hort. Dept. Fac. of Agric. Souhag Univ. Egypt.

Received October 15, 2021, Accepted, November 15, 2021. 
$\mathrm{Zn}$. It also plays an essential role in starch metabolism in plants. Iron plays a significant role in the chlorophyll biosynthesis pathway. Thus, this element's deficiency decreased photosynthesis, which resulted in a considerable reduction in yield.

In contrast to most macronutrients, magnesium does not form a significant part of mixed fertilizers in Egypt. Also, magnesium is not usually added to citrus trees as a regular matter. This element's rapid leaching through soil aggravates magnesium deficiency problems (Miller et al., 1990). It is also responsible for activating several enzymes, respiration, DNA, and RNA formation (Majer, 2004).

This study objective was to shed some light on the effect of single or combined applications of some antioxidants, magnesium and a mixture of micronutrients on vegetative growth characters, nutritional status yield, and quality of Valencia orange trees. Another goal is to select the best combination of antioxidants and the two nutrients responsible for obtaining an economic yield.

\section{MATERIALS AND METHODS}

This investigation was carried during the 2018/2019 and 2019/2020 seasons in al kawamil orchard at faculty of agriculture, sohag university on thirty-six uniforms 15 years old Valencia orange trees (Citrus sinensis L) were budded on Volkameriana lemon (Citrus volkameriana L.) rootstock grown in sandy soil. The trees are planted at a distance of $5 \times 5$ meters and receive adequate fertilizers, irrigated via the drip irrigation system and subject to the same cultural practices practiced in the orchard. The trees were selected nearly similar in growth vigor and healthy. The water table depth is not less than two meters. Soil analysis was done according to the procedures outline by Wilde et al. (1985).

Drip irrigation system was followed using well water containing $1200 \mathrm{ppm}$ electrical conductivity.

The experiment includes the following twelve treatments.

1- Control (spray with water only).

2- Spraying mixture of some micronutrients $(300 \mathrm{ppm} F$, 200 ppm Zn, 200 ppm Mn).

3- Spraying magnesium sulphate at $1 \%$.

4- Spraying ascorbic acid at $300 \mathrm{ppm}$.

5- Spraying salicylic acid at $300 \mathrm{ppm}$.

6- Spraying mixture of some micronutrients $(300 \mathrm{ppm} \mathrm{Fe}$, $200 \mathrm{ppm} \mathrm{Zn}, 200 \mathrm{ppm} \mathrm{Mn})+1 \%$ magnesium sulphate.

7- Spraying $300 \mathrm{ppm}$ ascorbic acid + mixture of some micronutrients ( 300 ppm Fe, $200_{\text {ppm }} \mathrm{Zn}, 200_{\mathrm{ppm}} \mathrm{Mn}$ ).

8- Spraying $300 \mathrm{ppm}$ salicylic acid + mixture of some micronutrients ( 300 ppm Fe, 200 ppm Zn, 200 ppm Mn).

Table 1. Analysis of the tested soil

\begin{tabular}{lc}
\hline Constituents & values \\
\hline Particle size distribution: & \\
\hline Sand \% & 89.60 \\
Silt \% & 5.85 \\
Clay \% & 4.55 \\
Texture\% & Sandy \\
pH $(1: 2.5$ extract) & 8.00 \\
O.M. \% & 0.08 \\
CaCO $\%$ & 3.10 \\
Total N \% & 0.05 \\
Available P (Olsen method) ppm & 1.6 \\
Available K (ammonium acetate) ppm & 185 \\
Mg meq/L & 3.28 \\
EDTA extractable micronutrients (ppm) & \\
Fe & 1.10 \\
Mn & 1.14 \\
$\mathrm{Zn}$ & 0.99 \\
\hline
\end{tabular}


9- Spraying $300 \mathrm{ppm}$ ascorbic acid $+1 \%$ magnesium sulphate.

10- Spraying 300 ppm salicylic acid $+1 \%$ magnesium sulphate.

11- Spraying $300 \mathrm{ppm}$ ascorbic acid $+1 \%$ magnesium sulphate + mixture of some micronutrients $(300 \mathrm{ppm}$ Fe, 200 ppm Zn, $200_{\text {ppm Mn). }}$

12- Spraying $300 \mathrm{ppm}$ salicylic acid $+1 \%$ magnesium sulphate + mixture of some micronutrients $(300 \mathrm{ppm}$ Fe, 200 ppm Zn, 200 ppm Mn).

Each treatment was replicated three times, one tree per each. The total selected trees for achieving of this study were 36 uniform trees. All antioxidants and micronutrients ( 300 ppm Fe, 200 ppm Zn, 200 ppm Mn) and magnesium sulphate $(9.6 \% \mathrm{Mg})$ were sprayed three times at growth start after fruits setting and at one month later. The assigned amounts of salicylic acid were solubilized in ethyl alcohol and $\mathrm{pH}$ of the solution was adjusted to 6.0 by using $1.0 \mathrm{~N}$ sodium hydroxide. Triton B as a wetting agent was added at $0.05 \%$ to all the investigated solutions, including the control. Spraying was done till runoff. The trees were covered entirely with solutions (5 liters/ tree). The selected trees received the same horticultural practices applied in the orchard except for two antioxidants or magnesium sulphate and micronutrient. The experiment was arranged in a complete randomized block design with three replicates, each replicate considered one tree

\section{During both seasons, the following parameters were recorded:}

Some vegetative growth characteristics include main shoot length $(\mathrm{cm})$, shoot thickness $(\mathrm{cm})$ and leave area $\left(\mathrm{cm}^{2}\right)$ (Ahmed and Morsy, 1999) in the spring growth cycle.

Fruit set percentage at full bloom Throughout each experimental season, fruit set $\%$ was calculated by (No. of total fruit set / No. of flower) $* 100$

Leaf contents of N, P, K, and $\mathrm{Mg}$ (as \%) Fe, Mn and $\mathrm{Zn}$ (as ppm) in the fresh leaves taken from non-fruiting shoots in the spring growth flush (1st week of Sept.) and dry weight basis (Summer, 1985).

Percentages of fruit retention, yield expressed in weight $(\mathrm{Kg})$ and number of fruits per tree at week $1{ }^{\text {st }}$ of march in two seasons.

Fruit physical and chemical characteristics, namely weight $(\mathrm{g})$, height and diameter of fruit $(\mathrm{cm})$, Fruit peel thickness $(\mathrm{cm})$, fruit peel weight percent, T.S.S \%, total acidity (as g citric acid/100 $\mathrm{ml}$ juice), T.S.S/acid ratio, percentages of total, reducing sugars, vitamin $\mathrm{C}$ content (mg/1000 ml juice) (A.O.A.C, 1995).

According to Mead et al., (1993), the obtained data were subjected to the proper statistical analysis, New
L.S.D. parameter at 5\% was used for made all comparisons among various treatment means.

\section{RESULTS AND DISCUSSION}

\section{Some vegetative growth characters:}

Table (2) Single and combined applications of the two antioxidants, namely ascorbic acid and salicylic acid, magnesium and micronutrients, effectively enhanced the leaf area and main shoot length compared with non-application. The promotion was concerned with using salicylic acid, ascorbic acid, magnesium and mixture of micronutrients in ascending order. The highest value was registered when the trees received sprays of a mixture containing salicylic acid (SA) at 300 $\mathrm{ppm}+$ magnesium sulphate at $1 \%+$ micronutrients $(300$ ppm Fe, 200 ppm Zn, 200 ppm Mn). Untreated trees produced the lowest values. Their effect could explain the increase in some vegetative growth characteristics under application of various levels of salicylic acid in enhancing division and enlargement of cells (Abada, 2014). Abdelmoniem et al. (2019) found that antioxidant materials significantly affected Navel orange growth, yield, fruit quality and nutritional status. The obtained results concerning the positive effect of micronutrient mixture ( $\mathrm{Fe}, \mathrm{Zn}$ and $\mathrm{Mn})$ in this regard are in agreement with those reported by Ilyas et al. (2015) on Kinnow mandarin, Suman et al. (2016) and Zagade et al. (2017) on guava, they indicated that foliar application of micronutrients such as $\mathrm{Fe}, \mathrm{Zn}$ and $\mathrm{Mn}$ alone or in combinations enhanced vegetative growth of the different fruit trees.

\section{Fruit set percentage (\%) and Fruit retention \%}

Table (2) displays that all treatments with salicylic acid, ascorbic acid, micronutrients, and magnesium alone or combined will significantly increase the fruit set value and Fruit retention value over control. However, containing salicylic acid (SA) at $300 \mathrm{ppm}+$ magnesium sulphate at $1 \%+$ micronutrients $(300 \mathrm{ppm}$ Fe, $200 \mathrm{ppm} \mathrm{Zn,} 200 \mathrm{ppm} \mathrm{Mn)} \mathrm{was} \mathrm{statistically}$ superior. Exhibited the greatest fruit set \% in Valencia orange trees 18.81 and $18.33 \%$ during the 2018/2019 and 2019/2020 experimental seasons, showed the greatest fruit retention in Valencia orange trees 1.75 and $1.67 \%$ during 2018/2019 and 2019/2020 experimental seasons, respectively. Also, control treatment was the least effective during both 2018/2019 and 2019/2020 experimental seasons. Increased fruit retention due to the application of micronutrients might have increased the number of fruits per tree, hence increasing yield in the present study. The obtained results concerning the positive effect of micronutrient mixture ( $\mathrm{Fe}, \mathrm{Zn}$ and $\mathrm{Mn}$ ) in this regard are in agreement with those reported by Ilyas et al. (2015) on Kinnow mandarin, Suman et al. (2016) and Zagade et al. (2017) on guava. They 
indicated that foliar application of micronutrients such as $\mathrm{Fe}, \mathrm{Zn}$ and $\mathrm{Mn}$ alone or in combinations enhanced fruiting parameters of the different fruit trees.

\section{Different nutrients in the leaves:}

It is clear from the data in Table 3 that single and combined applications of these substances, namely mixture of micronutrients ( $300 \mathrm{ppm} \mathrm{Fe}, 200 \mathrm{ppm} \mathrm{Zn}$, $200 \mathrm{ppm} \mathrm{Mn}$ ), magnesium at $1 \%$, salicylic acid (SA) at $300 \mathrm{ppm}$ and ascorbic acid at $300 \mathrm{ppm}$ were significantly associated with stimulating content of $\mathrm{N}, \mathrm{P}, \mathrm{K}, \mathrm{Mg}, \mathrm{Zn}$, $\mathrm{Mn}$ and $\mathrm{Fe}$ compared to the control treatment. The promotion effects were associated with using magnesium, ascorbic acid, salicylic acid (SA) and a mixture of micronutrients which were in ascending order. Meanwhile, combined applications of these substances were significantly superior than using each compound alone in this respect. The highest values were registered on the trees sprayed with salicylic acid (SA) at $300 \mathrm{ppm}+\mathrm{Mg}$ at $1 \%+$ micronutrients $(300 \mathrm{ppm} \mathrm{Fe}$, 200 ppm Zn, 200 ppm Mn). The lowest values were reported on untreated trees. During both seasons, a similar result was observed.

The essential roles of micronutrients, magnesium, salicylic acid (SA) and ascorbic acid on stimulating cell division, the biosynthesis of organic foods and the resistance of plants to all stresses (Rao et al., 2000, Singh et al., 2001 and Alonso, 2004) could explain the present results.

These results are in approval with those obtained by Eshmawy (2010), Saied (2011) and Ahmed (2011), who experimented on salicylic acid as well as Abdelmoniem et al. (2019) The nutritional status of Navel orange was significantly influenced by antioxidant materials. (ElKhayat, 2018) who worked on ascorbic acid sprays increased leaf nitrogen, potassium and calcium on Washington navel orange, also agree with the result of El-Tanany et al ., 2011.

The increase of the orange tree's nutrient content resulting from spraying different nutrient solutions may be attributed to rapid absorption via leaves and low nutrients. Such results may be attributed to $\mathrm{K}$ and $\mathrm{Zn}$ role in the plant, such as photosynthesis reactions, nucleic acid metabolism, protein, and carbohydrate biosynthesis due to increased leaf mineral content (Hafez and El-Metwally, 2007).

\section{Yield/ tree:}

It is worth mentioning that yield (table, 4) expressed in the number of fruits and weight (kg.) per tree was significantly improved in response to foliar application mixture of micronutrients $(300 \mathrm{ppm} \mathrm{Fe}, 200$ ppm Zn, $200 \mathrm{ppm}$ Mn), magnesium at $1 \%$, salicylic acid (SA) at $300_{\mathrm{ppm}}$ and ascorbic acid at $300 \mathrm{ppm}$ either alone or in all possible combinations comparing with the control treatment. Using ascorbic acid, magnesium, micronutrients and salicylic acid (SA), in ascending order was significantly followed by enhancing yield. Applications of these substances were preferable to using each substance alone in this respect. The maximum yield expressed in weight (kg.) (18.03 and $16.90 \mathrm{~kg}$ ) was recorded on the trees that received sprays of salicylic acid (SA) at $300 \mathrm{ppm}+$ magnesium sulphate at $1 \%+$ micronutrients at $(300 \mathrm{ppm}$ Fe, $200 \mathrm{ppm} \mathrm{Zn}$, $\left.200_{\mathrm{ppm}} \mathrm{Mn}\right)$ during both seasons, respectively. The lowest values ( 8.50 and $8.93 \mathrm{~kg} /$ tree) during both seasons, respectively, were recorded on untreated trees. A similar trend was noticed during both seasons.

The promotive effects of these stimulants on growth and tree nutritional status in favor of enhancing $\mathrm{C} / \mathrm{N}$ ratio and producing a higher number of flowers could improve the yield. It is suggested that the increase in bio productivity is mainly due to the positive effect of SA on root length and its density. (Shaaban and Mahmoud, 2012).

These results are in approval with those obtained by Eshmawy (2010), Saied (2011) and Ahmed (2011), who worked on salicylic acid as well as Abdelmoniem et al. (2019) found that antioxidant materials were affected significantly on Navel orange yield. Saha et al. (2020) found that foliar spray of $\mathrm{ZnSO}_{4}$ at $0.6 \%$ was suggested to improve yield on sweet orange.

\section{Some physical and chemical characteristics of the fruits:}

Tables (4 and 5) showed that single and combined applications of micronutrients (300 ppm Fe, $200 \mathrm{ppm} \mathrm{Zn}$, $200 \mathrm{ppm} \mathrm{Mn}$ ), magnesium at $1 \%$, salicylic acid (SA) at $300 \mathrm{ppm}$ and ascorbic acid at $300 \mathrm{ppm}$ significantly improved fruit quality in terms of increasing fruit weight, fruit height, fruit diameter, total soluble solids, total and reducing sugars and vitamin $\mathrm{C}$ content rather and decreasing fruit peel weight and thickness and total acidity \% over the check treatment. A significant promotion was observed on fruit quality due to foliar application of ascorbic acid, magnesium, micronutrients and salicylic acid (SA) in ascending order. Combined applications were favourable than using single ones in this respect. The best results concerning fruit quality were obtained with salicylic acid (SA) at $300 \mathrm{ppm}+$ magnesium sulphate at $1 \%+$ micronutrients $(300 \mathrm{ppm} F$, 200 ppm Zn, 200 ppm Mn). Untreated trees produced unfavorable effects on fruit quality. These results were true during both seasons. 
Table 2. Effect of some antioxidants, micronutrients and magnesium treatments on some vegetative growth, fruit set \%, Fruit retention\% and number of fruits/tree of Valencia orange trees during 2018/2019 and2019/ 2020 seasons.

\begin{tabular}{|c|c|c|c|c|c|c|c|c|c|c|c|c|}
\hline \multirow[t]{2}{*}{ Treatment } & \multicolumn{2}{|c|}{$\begin{array}{l}\text { Main shoot } \\
\text { length }(\mathrm{cm})\end{array}$} & \multicolumn{2}{|c|}{$\begin{array}{c}\text { Shoot } \\
\text { thickness }(\mathrm{cm})\end{array}$} & \multicolumn{2}{|c|}{$\begin{array}{l}\text { Leaf area } \\
(\mathrm{cm})^{2}\end{array}$} & \multicolumn{2}{|c|}{$\begin{array}{c}\text { Fruit set } \\
\%\end{array}$} & \multicolumn{2}{|c|}{$\begin{array}{c}\text { Fruit } \\
\text { retention \% }\end{array}$} & \multicolumn{2}{|c|}{$\begin{array}{c}\text { No. of } \\
\text { fruits/tree }\end{array}$} \\
\hline & $18 / 19$ & $19 / 20$ & $18 / 19$ & $19 / 20$ & $18 / 19$ & $19 / 20$ & 18/19 & $19 / 20$ & 18/19 & $19 / 2$ & $18 / 19$ & $19 / 20$ \\
\hline Control & 5.40 & 5.53 & 0.11 & 0.12 & 24.83 & 24.03 & 8.86 & 8.53 & 1.11 & 1.10 & 44.8 & 47.00 \\
\hline Micronutrient & 7.00 & 7.40 & 0.16 & 0.17 & 27.93 & 26.86 & 14.25 & 13.74 & 1.29 & 1.30 & 67.27 & 60.54 \\
\hline $\mathrm{Mg}$ at $1 \%$ & 6.63 & 7.20 & 0.15 & 0.15 & 26.20 & 25.80 & 10.47 & 9.81 & 1.23 & 1.25 & 65.7 & 60.10 \\
\hline ascorbic acid at $300 \mathrm{ppm}$ & 6.30 & 6.50 & 0.14 & 0.15 & 26.33 & 25.83 & 12.35 & 11.63 & 1.20 & 1.20 & 47.57 & 54.36 \\
\hline salicylic acid at $300 \mathrm{ppm}$ & 5.83 & 6.27 & 0.14 & 0.14 & 26.13 & 25.73 & 12.44 & 12.56 & 1.16 & 1.15 & 59.70 & 57.91 \\
\hline micronutrient $+\mathrm{Mg}$ at $1 \%$ & 7.56 & 7.53 & 0.22 & 0.19 & 27.76 & 27.00 & 15.51 & 14.5 & 1.35 & 1.32 & 76.8 & 61.37 \\
\hline ascorbic acid + micro & 7.80 & 7.70 & 0.24 & 0.22 & 28.33 & 27.06 & 16.38 & 15.39 & 1.57 & 1.48 & 69.3 & 65.61 \\
\hline salicylic acid + micro & 8.10 & 8.46 & 0.24 & 0.25 & 28.56 & 27.83 & 16.90 & 16.4 & 1.64 & 1.55 & 77.2 & 69.72 \\
\hline ascorbic acid $+\mathrm{Mg}$ at $1 \%$ & 8.30 & 9.23 & 0.28 & 0.2 & 28.73 & 28.50 & 13.27 & 12.92 & 1.41 & 1.37 & 66.9 & 64.18 \\
\hline salicylic acid $+\mathrm{Mg}$ at $1 \%$ & 8.80 & 9.83 & 0.31 & 0.32 & 29.13 & 28.66 & 13.36 & 13.45 & 1.48 & 1.40 & 69.89 & 63.32 \\
\hline ascorbic acid $+\mathrm{Mg}+$ micro & 9.60 & 10.03 & 0.33 & 0.31 & 29.04 & 29.22 & 17.68 & 16.87 & 1.70 & 1.61 & 80.32 & 74.91 \\
\hline salicylic acid $+\mathrm{Mg}+$ micro & 10.30 & 10.60 & 0.37 & 0.36 & 30.93 & 31.00 & 18.81 & 18.33 & 1.75 & 1.67 & 80.13 & 76.04 \\
\hline New L.S.D at $5 \%$ & 0.4 & 0.4 & 0.03 & 0.04 & 1.6 & 1.7 & 0.37 & 0.37 & 0.05 & 0.05 & 5.0 & 5.0 \\
\hline
\end{tabular}

Table 3. Effect of some antioxidant, micronutrients and magnesium treatments on nutritional status of Valencia orange trees during $2018 / 2019$ and2019/ 2020 seasons.

\begin{tabular}{|c|c|c|c|c|c|c|c|c|c|c|c|c|c|c|}
\hline \multirow[t]{2}{*}{ Treatment } & \multicolumn{2}{|c|}{ Leaf N\% } & \multicolumn{2}{|c|}{ Leaf P \% } & \multicolumn{2}{|c|}{ Leaf K \% } & \multicolumn{2}{|c|}{ Leaf Mg \% } & \multicolumn{2}{|c|}{ Leaf Fe (ppm) } & \multicolumn{2}{|c|}{ Leaf Mn } & \multicolumn{2}{|c|}{ Leaf Zn } \\
\hline & $18 / 19$ & $19 / 20$ & $18 / 19$ & $19 / 20$ & $18 / 19$ & $19 / 20$ & $18 / 19$ & $19 / 20$ & $18 / 19$ & $19 / 20$ & $18 / 19$ & $19 / 20$ & $18 / 19$ & $19 / 20$ \\
\hline Control & 1.42 & 1.45 & 0.11 & 0.12 & 1.13 & 1.16 & 0.27 & 0.29 & 59.88 & 60.77 & 56.87 & 57.20 & 49.30 & 48.76 \\
\hline Micronutrient & 1.83 & 1.87 & 0.23 & 0.27 & 1.52 & 1.60 & 0.34 & 0.35 & 67.89 & 70.55 & 67.00 & 65.40 & 60.33 & 61.52 \\
\hline $\mathrm{Mg}$ at $1 \%$ & 1.59 & 1.62 & 0.15 & 0.14 & 1.48 & 1.57 & 0.52 & 0.53 & 62.55 & 63.44 & 60.13 & 61.16 & 53.96 & 55.56 \\
\hline ascorbic acid at $300 \mathrm{ppm}$ & 1.64 & 1.68 & 0.23 & 0.18 & 1.50 & 1.59 & 0.38 & 0.39 & 65.88 & 67.88 & 62.20 & 63.44 & 52.70 & 52.43 \\
\hline salicylic acid at $300 \mathrm{ppm}$ & 1.52 & 1.56 & 0.12 & 0.16 & 1.23 & 1.24 & 0.32 & 0.32 & 64.25 & 65.55 & 63.86 & 67.67 & 55.26 & 55.66 \\
\hline micronutrient $+\mathrm{Mg}$ at $1 \%$ & 1.88 & 1.93 & 0.25 & 0.27 & 1.24 & 1.30 & 0.55 & 0.56 & 71.44 & 74.22 & 71.40 & 72.40 & 63.33 & 64.77 \\
\hline ascorbic acid + micro & 1.86 & 1.90 & 0.16 & 0.27 & 1.28 & 1.34 & 0.44 & 0.46 & 81.66 & 80.88 & 80.00 & 8.00 & 73.00 & 74.66 \\
\hline salicylic acid + micro & 1.69 & 1.74 & 0.18 & 0.2 & 1.33 & 1.39 & 0.40 & 0.40 & 83.9 & 82.44 & 82.00 & 82.70 & 75.36 & 75.73 \\
\hline ascorbic acid + Mg at $1 \%$ & 1.74 & 1.80 & 0.20 & 0.23 & 1.39 & 1.46 & 0.49 & 0.49 & 72.8 & 75.44 & 72.70 & 73.70 & 67.33 & 68.97 \\
\hline salicylic acid + Mg at $1 \%$ & 1.80 & 1.87 & 0.21 & 0.25 & 1.46 & 1.54 & 0.54 & 0.55 & 76.55 & 79.88 & 75.66 & 76.03 & 69.33 & 70.66 \\
\hline ascorbic acid $+\mathrm{Mg}+$ micro & 1.85 & 1.91 & 0.24 & 0.28 & 1.49 & 1.59 & 0.54 & 0.55 & 85.44 & 84.03 & 82.03 & 81.33 & 76.03 & 76.07 \\
\hline salicylic acid $+\mathrm{Mg}+$ micro & 1.92 & 1.97 & 0.27 & 0.3 & 1.54 & 1.65 & 0.58 & 0.60 & 88.11 & 87.11 & 86.00 & 85.00 & 79.30 & 78.66 \\
\hline New L.S.D at $5 \%$ & 0.04 & 0.06 & 0.02 & 0.01 & 0.04 & 0.04 & 0.04 & 0.04 & 2.3 & 2.8 & 2.8 & 3.1 & 2.9 & 2.4 \\
\hline
\end{tabular}


Table 4. Effect of some antioxidants, micronutrients and magnesium treatments on Yield and Fruit quality of Valencia orange trees during $2018 / 2019$ and2019/ 2020 seasons.

\begin{tabular}{|c|c|c|c|c|c|c|c|c|c|c|c|c|}
\hline \multirow[t]{2}{*}{ Treatment } & \multicolumn{2}{|c|}{ Yield/tree (Kg) } & \multicolumn{2}{|c|}{ Fruit weight (g) } & \multicolumn{2}{|c|}{$\begin{array}{c}\text { Fruit } \\
\text { height }(\mathbf{c m})\end{array}$} & \multicolumn{2}{|c|}{$\begin{array}{c}\text { Fruit } \\
\text { diameter }(\mathbf{c m})\end{array}$} & \multicolumn{2}{|c|}{$\begin{array}{c}\text { Fruit peel } \\
\text { thickness }(\mathbf{c m})\end{array}$} & \multicolumn{2}{|c|}{$\begin{array}{l}\text { Fruit peel } \\
\text { weight } \%\end{array}$} \\
\hline & $18 / 19$ & $19 / 20$ & $18 / 19$ & $19 / 20$ & $18 / 19$ & $19 / 20$ & $18 / 19$ & $19 / 20$ & $18 / 19$ & $19 / 20$ & $18 / 19$ & $19 / 20$ \\
\hline Control & 8.50 & 8.93 & 189.67 & 190.00 & 7.24 & 7.02 & 6.53 & 6.30 & 0.29 & 0.28 & 22.43 & 22.70 \\
\hline Micronutrient & 13.52 & 11.88 & 203.00 & 197.67 & 7.56 & $7.2 \wedge$ & 6.67 & 6.43 & 0.26 & 0.25 & 21.63 & 21.10 \\
\hline $\mathrm{Mg}$ at $1 \%$ & 12.12 & 11.6 & 203.00 & 200.33 & 7.46 & 7.24 & 6.67 & 6.43 & 0.27 & 0.26 & 22.36 & 22.30 \\
\hline ascorbic acid at $300 \mathrm{ppm}$ & 9.04 & 10.33 & 190.00 & 190.22 & 7.46 & $7.2 \varepsilon$ & 6.59 & 6.36 & 0.22 & 0.22 & 20.36 & 20.55 \\
\hline salicylic acid at $300 \mathrm{ppm}$ & 13.77 & 12.33 & 203.33 & 203.67 & 7.60 & 7.30 & 6.71 & 6.48 & 0.24 & 0.23 & 19.9 & 19.56 \\
\hline micronutrient $+\mathrm{Mg}$ at $1 \%$ & 13.50 & 12.56 & 194.67 & 204.67 & 7.64 & 7.32 & 6.76 & 6.53 & 0.25 & 0.24 & 21.13 & 20.80 \\
\hline ascorbic acid + micro & 15.88 & 13.56 & 206.67 & 206.67 & 7.71 & 7.65 & 6.80 & 6.85 & 0.21 & 0.22 & 19.80 & 19.50 \\
\hline salicylic acid + micro & 16.02 & 14.96 & 207.33 & 210.67 & 7.93 & 7.95 & 6.88 & 6.85 & 0.20 & 0.24 & 19.22 & 19.30 \\
\hline ascorbic acid $+\mathrm{Mg}$ at $1 \%$ & 13.88 & 12.90 & 207.33 & 201.00 & 7.97 & 7.65 & 6.90 & 6.67 & 0.22 & 0.23 & 20.00 & 20.05 \\
\hline salicylic acid + Mg at $1 \%$ & 14.70 & 13.15 & 210.33 & 207.67 & 8.05 & 7.73 & 6.94 & 6.91 & 0.22 & 0.23 & 19.90 & 19.80 \\
\hline ascorbic acid $+\mathrm{Mg}+$ micro & 17.25 & 16.18 & 215.00 & 216.00 & 8.07 & 8.10 & 6.96 & 6.95 & 0.20 & 0.21 & 19.60 & 19.48 \\
\hline salicylic acid $+\mathrm{Mg}+$ micro & 18.03 & 16.90 & 225.00 & 222.33 & 8.29 & 8.22 & 7.11 & 7.12 & 0.19 & 0.20 & 19.03 & 18.83 \\
\hline New L.S.D at $5 \%$ & 1.3 & 1.2 & 11.5 & 10.22 & 0.21 & 0.21 & 0.12 & 0.12 & 0.03 & 0.02 & 0.53 & 0.53 \\
\hline
\end{tabular}

Table 5. Effect of some antioxidants, micronutrients and magnesium treatments on Fruit quality of Valencia orange trees during 2018/2019 and 2019/ 2020 seasons.

\begin{tabular}{|c|c|c|c|c|c|c|c|c|c|c|c|c|}
\hline \multirow[t]{2}{*}{ Treatment } & \multicolumn{2}{|c|}{ T.S.S \% } & \multicolumn{2}{|c|}{$\begin{array}{c}\text { Total } \\
\text { acidity } \%\end{array}$} & \multicolumn{2}{|c|}{ TSS/acid ratio } & \multicolumn{2}{|c|}{ Total sugars \% } & \multicolumn{2}{|c|}{$\begin{array}{l}\text { Reducing } \\
\text { sugars \% }\end{array}$} & \multicolumn{2}{|c|}{$\begin{array}{c}\text { Vitamin } \mathrm{C} \text { content } \\
\text { (mg/100g juice) }\end{array}$} \\
\hline & $18 / 19$ & $19 / 20$ & $18 / 19$ & $19 / 20$ & $18 / 19$ & $19 / 20$ & $18 / 19$ & $19 / 20$ & $18 / 19$ & $19 / 20$ & $18 / 19$ & $19 / 20$ \\
\hline Control & 10.33 & 11.07 & 0.85 & 0.965 & 12.15 & 11.47 & 6.93 & 6.96 & 3.06 & 3.03 & 50.33 & 48.33 \\
\hline Micronutrient & 10.55 & 11.50 & 0.823 & 0.844 & 12.81 & 13.62 & 7.23 & 7.00 & 3.29 & 3.20 & 52.77 & 50.9 \\
\hline $\mathrm{Mg}$ at $1 \%$ & 10.66 & 11.66 & 0.83 & 0.874 & 12.84 & 13.34 & 7.307 & 7.16 & 3.36 & 3.30 & 53.33 & 50.55 \\
\hline ascorbic acid at $300 \mathrm{ppm}$ & 10.8 & 11.75 & 0.78 & 0.82 & 13.84 & 14.32 & 7.46 & 7.33 & 3.46 & 3.46 & 54.99 & 51.33 \\
\hline salicylic acid at $300 \mathrm{ppm}$ & 11.34 & 12.05 & 0.75 & 0.819 & 15.12 & 14.71 & 7.63 & 7.40 & 3.70 & 3.66 & 52.22 & 50.50 \\
\hline micronutrient $+\mathrm{Mg}$ at $1 \%$ & 11.40 & 12.15 & 0.75 & 0.81 & 15.20 & 15.00 & 7.93 & 7.66 & 3.76 & 3.80 & 56.44 & 53.22 \\
\hline ascorbic acid + micro & 11.44 & 12.20 & 0.733 & 0.747 & 15.61 & 16.33 & 8.13 & 7.86 & 3.83 & 3.93 & 55.88 & 51.2 \\
\hline salicylic acid + micro & 11.54 & 12.30 & 0.72 & 0.747 & 16.02 & 16.46 & 8.30 & 8.33 & 4.13 & 4.03 & 56.88 & 52.33 \\
\hline ascorbic acid $+\mathrm{Mg}$ at $1 \%$ & 11.77 & 12.55 & 0.744 & 0.788 & 15.81 & 15.92 & 8.46 & 8.56 & 4.30 & 4.13 & 54.88 & 53.5 \\
\hline salicylic acid $+\mathrm{Mg}$ at $1 \%$ & 11.77 & 12.60 & 0.74 & 0.788 & 15.90 & 15.98 & 8.56 & 8.76 & 4.40 & 4.30 & 59.55 & 55.58 \\
\hline ascorbic acid $+\mathrm{Mg}+$ micro & 12.55 & 12.66 & 0.652 & 0.722 & 19.24 & 17.53 & 8.73 & 8.86 & 4.50 & 4.43 & 63.22 & 58.22 \\
\hline salicylic acid $+\mathrm{Mg}+$ micro & 12.55 & 13.55 & 0.65 & 0.722 & 19.30 & 18.76 & 8.90 & 8.93 & 4.70 & 4.63 & 60.22 & 57.88 \\
\hline New L.S.D at $5 \%$ & 0.22 & 0.53 & 0.01 & 0.01 & 0.42 & 0.42 & 0.23 & 0.23 & 0.22 & 0.14 & 2.0 & 2.1 \\
\hline
\end{tabular}


The beneficial effects of these stimulants on enhancing nutrients, especially, $\mathrm{Zn}, \mathrm{Fe}$ and $\mathrm{Mg}$ were accompanied by enhancing and promoting fruit quality.

These results are in approval with those obtained by Eshmawy (2010); Saied (2011) and Ahmed (2011), who worked on salicylic acid as well as Abdelmoniem et al. (2019) salicylic acid gave the highest significant values of fruit weight on Navel orange. (El-Khayat, 2018) worked on ascorbic acid sprays, increased fruit length, and fruit diameter on Washington navel orange. Respectively. Zinc rapidly increases photosynthetic activity and photosynthetic transmission, leading to fruit size enlargement (Graham et al., 2000). Ram and Bose (2000) found that foliar spraying with high percentages of $\mathrm{Mg}$ and micronutrients $(\mathrm{Cu}, \mathrm{Zn}, \mathrm{Fe}, \mathrm{B})$ on mandarin trees had a non-significant effect on TSS, total sugar, reducing sugars. Lower acidity in fruits may have resulted in increased accumulation of sugars, better translocation of sugars via fruit tissues and transformation of organic acids into sugars (Kumar et al., 2015).

In conclusion, it is evident from the data obtained that the Valencia orange trees planted in Sohag region were treated three times (at growth start, just after fruits setting and at one month later) with a mixture of salicylic acid (SA) at $300 \mathrm{ppm}+$ magnesium sulphate at $1 \%+$ micronutrients $(300$ ppm Fe, 200 ppm Zn, 200 ppm Mn) was responsible for promoting yield quantitively and qualitatively.

\section{REFERENCES}

Abada, M.A. 2014. A comparative study for the effect of green tea extract and some antioxidants on Thompson seedless grapevines. Int. J. of Plant \& Soil Sci. 3(10), 1333-1342.

Abdelmoniem, E.M., S.A. El-Shazly, A.A. El-Gazzar and N.A. Mansour 2019. Effect of spraying with some antioxidants on growth, yield, fruit quality and nutritional status of 'Navel Orange' trees. Arab Univ. J. Agric. Sci., Ain Shams Univ., Cairo, Egypt 27(2), 1559-1576.

Ahmed, E. F. S. 2011. Response of Sakkoti date palms to foliar application of salicylic acid. Minia J. of Agric. Res. \& Develop. Vol. (31): No. 2 pp 305 - 316.

Ahmed, F. F and M. H. Morsy. 1999. A new method for measuring leaf area in different fruit species. Minia J. of Agric. Res.\& Develop., Vol. (19) pp 97 - 105.

Alonso, J. 2004. Tratado de Fitofarmocos y Nutraceutices, Barcelona Corpus p 395 - 403.

Association of Official Agricultural Chemists. 1995. Official Methods of Analysis $15^{\text {th }}$ Ed., A.O.A.C., Washington, D.C. U.S.A. pp. $490-520$.
Dehghan, G., L. Rezazadeh and G. Habibi. 2011. Exogenous ascorbate improves antioxidant defence system and induces salinity tolerance in soybean seedlings. Act. Biol. Szegeb. 55: 261-266.

El-Khayat, M.I. 2018. effect of gibberellin and some antioxidants pre-harvest foliar application on yield, fruit quality and shelf life of Washington Navel Orange. Zagazig J. Agric. Res., Vol. 45 No. (2): 477-494.

El-Sayed, M. A., M. A. Ahmed and A. H. Ali. 2000. Response of Flame seedless grapevine to application of ascorbic acid. The2nd Conf. Sci. Assuit, Egypt ; 317-340.

El-Tanany, M.M., M.N. Abdel Messih and M.A. Shama. 2011. Effect of Foliar Application with Potassium, Calcium and Magnesium on Yield, Fruit Quality and Mineral Composition of Washington Navel Orange Trees. Alex. Sci . Exch. J. 32: 65-75.

Eshmawy, E. M. Sh. 2010. Effect of some antioxidants and different pollination methods on fruiting of Sewy mould (Sclerotiorim spp.) in various crops. Plants Path. 141: 417 -426 .

Gordon, L.K., F.V. Minibayeva, T.I. Ogerodnikova, D. F. Rakhmatullina, A. N. Tzentzevitzky, O. P. Kolesnikov, D. A. Maksyutin and J. N. Valitova. 2002. Salicylic acid induced dissipation of the portion gradient on the plant cell membrane. Doklady Biol. Sci. 387: 581 - 583.

Graham, R. D., R.M. Welch and H.E. Bouis. 2000. Addressing micronutrient nutrition through enhancing the nutritional quality of staple foods. Adv. Agron. 70:77-61.

Hafez, O.M and I. M. El- Metwally. 2007. Efficiency of zinc and potassium sprays alone or in combination with some weed control treatments on weeds growth, yield and fruit quality of Washington navel orange orchards. Journal of Appl. Science Research, 3: 613-621.

Hayat, S and A. Ahmad. 2007. Salicylic Acid a Plant Hormone. Chapter 1, 2 Springer Publishers, Dordrecht, The Netherlands. Hayat, Q; Hayat, Sh., Irfan, M. and Ahmed. A. (2010). Effect of exogenous salicylic acid under charging environmental: A review. Env. Ed Exp. Botany 68: 14-25.

Ilyas, A., M.Y. Ashraf, M. Hussain, M. Ashraf, R. Ahmed and A. Kamal. 2015. Effect of micronutrients ( $\mathrm{Zn}, \mathrm{Cu}$ and $\mathrm{B}$ ) on photosynthetic and fruit yield attributes of Citrus reticulata Blanco var. kinnow. Pak. J. Bot., 47(4): 12411247.

Kumar, J., R. Kumar, R. Rai and D.S. Mishra. 2015. Response of 'Pant Prabhat' guava trees to foliar sprays of zinc, boron, calcium and potassium at different plant growth stages. Bioscan. 10(2):495-498.

Majer, J. 2004. Magnesium supply of the vineyards in the Balaton- Highlands. Proc. of the $1^{\text {st }}$ Inter. Soc of Grapevine. Acta. Hort. 652 pp. 175 - 18 .

Mead, R., R. N. Currnow and A. M. Harted. 1993. Statistical Methods in Agricultural and Experimental Biology. $2^{\text {nd }}$ Ed. Chapman \& Hall London. pp $10-14$. 
Miller, R.W., R.L. Donahve and J.U. Miller. 1990. Soils. An Introduction to Soil and Plant Growth" Prentice Hall inter increase. Englewood Cliffs, New Jersy pp. 380- 339.

Popova, L., T. Pancheva and A. Uzunova. 1997. Salicylic acid: properties, biosynthesis and hysiological role. Bulg. 1. Plant Physiol., 23: 85 - 93.

Ram, R. A and T. K. Bose. 2000. Effect of foliar application of magnesium and micronutrients on growth, yield and fruit quality of mandarin orange (Citrus reticulate Blanco). Indian. J. Hort .57:215-220.

Rao, M. V., J. R. Koch and K. R. Davis. 2000. Ozone a total for robbing programmed cell death in plants. Plant Mol. Bid. 44: 346 - 358.

Raskin, I. 1992a. Salicyiata, a new plant hormone. Plant Physiol. 99: 799 - 803.

Raskin, I. 1992b. Role of salicylic acid in plants. Ann. Rev. Plant Physiol. Plant Mol. Biol. 43: 439 - 463.

Raskin, I., H. Skubatz, W. Tang and B. J. D. Meeus. 1999. Salicylic acid levels in thermogenic and monthermogenic plants. Ann. Bot. 66: 376 - 383 .

Saha, T., A. Das, B. Ghosh, S. Kundu and S. Bhattacharya. 2020. Effect of micronutrients on fruit set, yield and quality of sweet orange (Citrus sinensis Osbeck) cv. Mosambi in the Gangetic alluvial region of West Bengal. Journal of Pharmacognosy and Phytochemistry; 9(3): 1793-1795.

Saied, H. H. M. 2011. Insight on the effects of salicylic acid on fruiting of Williams banana. Minia J. of Agric. Res. \& Develop. Vol. (31) No. 2 pp 317 - 326.

Shaaban, S. H. A and M. S. Mahmoud. 2012. Impact of the Nutritional Status on Yield of Nine Mango Cultivars Grown Under Farm Conditions at Giza, Governorate, Egyp. Journal of American Science, 8(5). pp 304-310.
Shoeib, M. M and A. El sayed. 2003. Response of "Thompson Seedless" grape vines to the spray of some nutrients and citric acid. Minia J. Agric. Res. Dev. 23(4): 681 - 698.

Singh, D. V., G. C. Srivastva and M. Z. Abdin. 2001. Amelioration of negative effect of water stress in Gassia anqustifolia by benzyladenine and/ or ascorbic acid. Biologia Plantarum.44 (1): 141 - 143.

Suman, M., S.V. Dubalgunde, O. Poobalan and D. P. Sangma. 2016. Effect of foliar application of micronutrients on yield and economics of guava (Psidium guajava L.) CV. L-49. International Journal of Agriculture, Environment and Biotechnology, 9(2): 221-224.

Summer, M. E. 1985. Dignosis and Recommendation Integrated System (DRIS) as a Guide to Orchard Fertilization. Hort. Abst. 55 (8): 7502.

Saha, T., A. Das, B. Ghosh, S. Kundu and S. Bhattacharya. 2020. Effect of micronutrients on fruit set, yield and quality of sweet orange (Citrus sinensis Osbeck) cv. Mosambi in the Gangetic alluvial region of West Bengal. Journal of Pharmacognosy and Phytochemistry; 9(3): 1793-1795.

Tariq, M., M. Sharif, Z. Shah and R. Khan. 2007. Effect of foliar application of micronutrients on the yield and quality of sweet orange (Citrus sinesis L.). Pakistan J. Biol. Sci., 10(11): 1823-1828.

Van Loon, L.C. 1995. Pathogenesis-related proteins. Plant Mol. Biol. 4, 111-116.

Wilde, S. A., R. B. Corey, J. G. Layer and G. K. Voigt. 1985. Soils and Plant Analysis for Tree Culture. Oxford, and IBH, New Delhi, India, pp. 1 - 142.

Zagade, P. M., G.R. Munde and A.H. Shirsath. 2017. Effect of foliar application of micronutrients on yield and quality of guava (Psidium guajava L.) Cv. Sardar. Journal of Pharmacy and Biological Sciences. 12 (5): 56-58. 


\section{الملخص العربي}

استجابة أثجار البرتقال الفالنشيا للرش الورقي ببعض مضادات الاكسدة (حامض السلسليك وحمض الإض

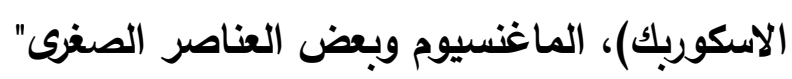

محمود رياض جاد الكريم، محمد احمد حسين

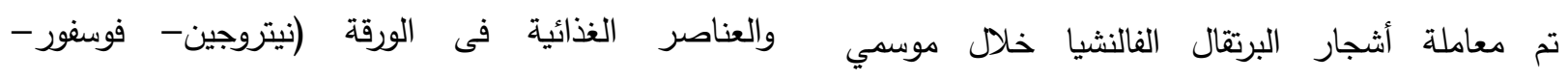

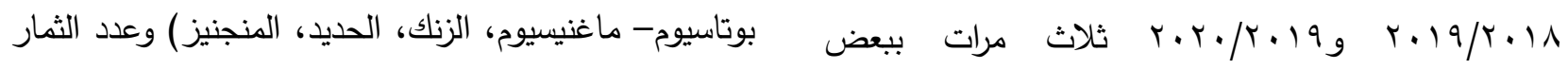

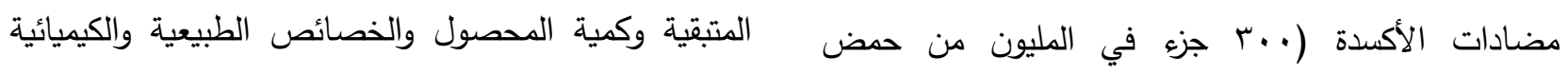
للثمار وذلك بالمقارنة بمعاملة الكونترول.

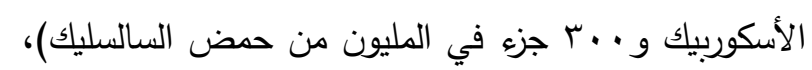

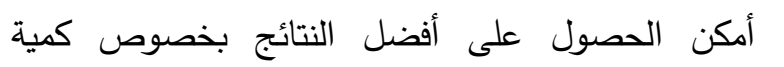

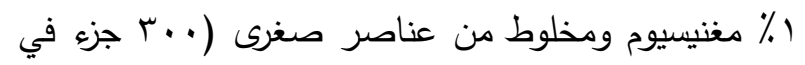
المحصول وجودة الثمار لأثجار البرتقال فالنسيا عند الرش الثرات

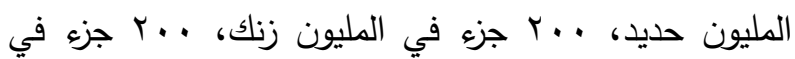
الورقي للأشجار ثلاث مرات (بدء النمو، بعد العقد وبعد شهر التهار

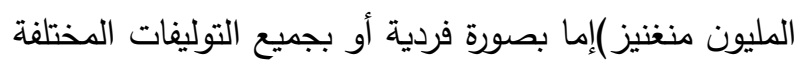
واحد) من مخلوط يحتوي على حض المض السالسليك بتركيز ولقد تم دراسة درجة استجابة مساحة الورقة ومحتواها من

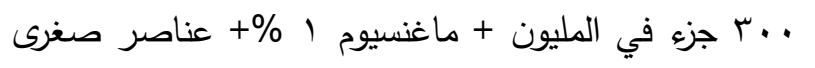

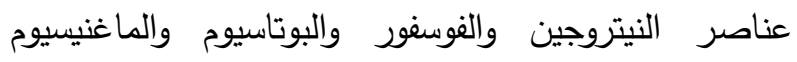

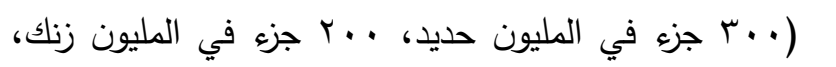

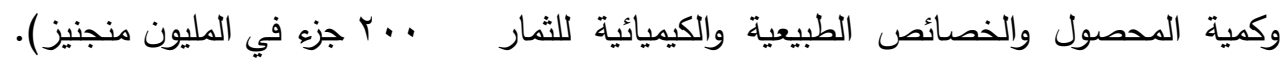

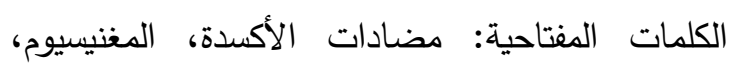
لهذه المعاملات. العناصر الصغرى، البرتقال الفالنثيا. كان الاستخدام الفردي والهشترك لهذه المواد فعالا جدا فى في تحسين مساحة الورقة وطول وسك النمو الخضرى 